
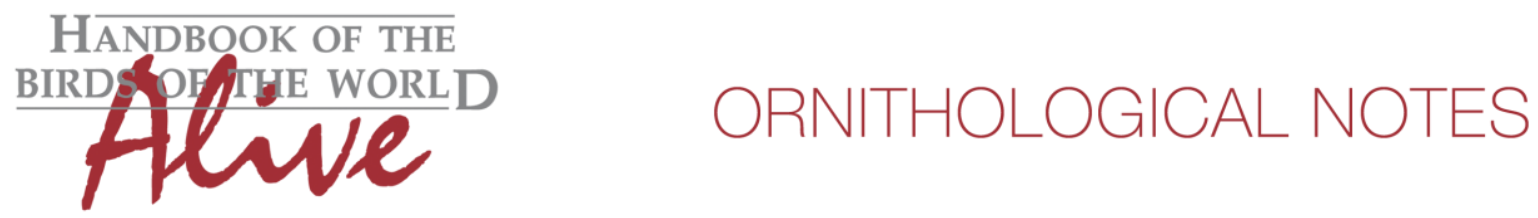

\title{
Notes on the vocalizations of Pale-breasted Spinetail (Synallaxis albescens)
}

Peter Boesman

In the following we briefly analyze and compare voice of the different races of Pale-breasted Spinetail (Synallaxis albescens). We also try to quantify the extent of any vocal differences using the criteria proposed by Tobias et al. (2010), as a support for taxonomic review. We have made use of sound recordings available on-line from Xeno Canto (XC) and Macaulay (ML).

A quick look at sonograms from all over its range, quickly reveals that there is one group clearly different from all others: (part of) S. a. australis

The song of all races except (part of) australis is a repeated phrase of two notes. The first note is upslurred with a sharp rise at the end. The second note is very burry, after a sharp initial rise descending in pitch (maximum pitch about the level of the final spike frequency) (Fig. 1). Amplitude typically increases towards the end in the first note and starts at equal or higher level in the second note after which it decreases. There are differences among some races which seem to be constant (higher-pitched S of Amazon).

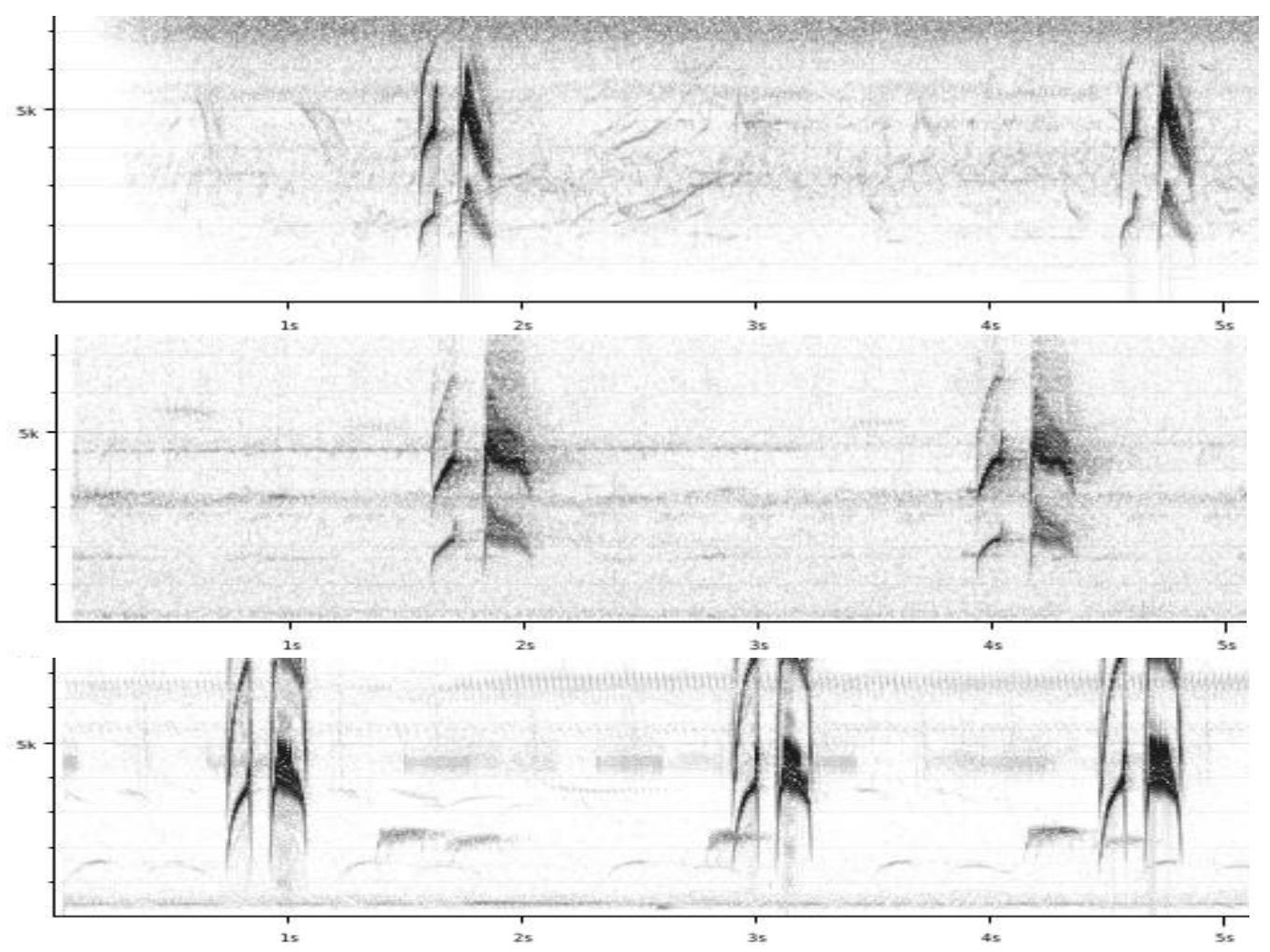

Figure 1: top to bottom: typical song from Costa Rica, Venezuela and SE Brazil 

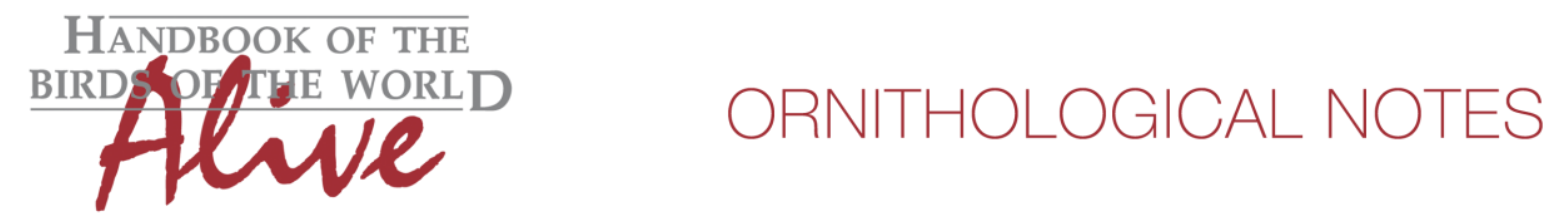

Song of (part of) S.a. australis is also a repeated phrase of 'two' notes, however:

- The first note is a sharply overslurred note, very burry (occasionally only slightly burry).

- The 'second note' is actually two notes: one sharply rising immediately followed by one sharply falling, without any burry quality. This can also be seen on the amplitude graph which clearly shows two peaks for the 'second note'. (The repetition is so fast it can't be heard by human ear as two separate notes, and very occasionally the two notes are linked forming an overslurred note).
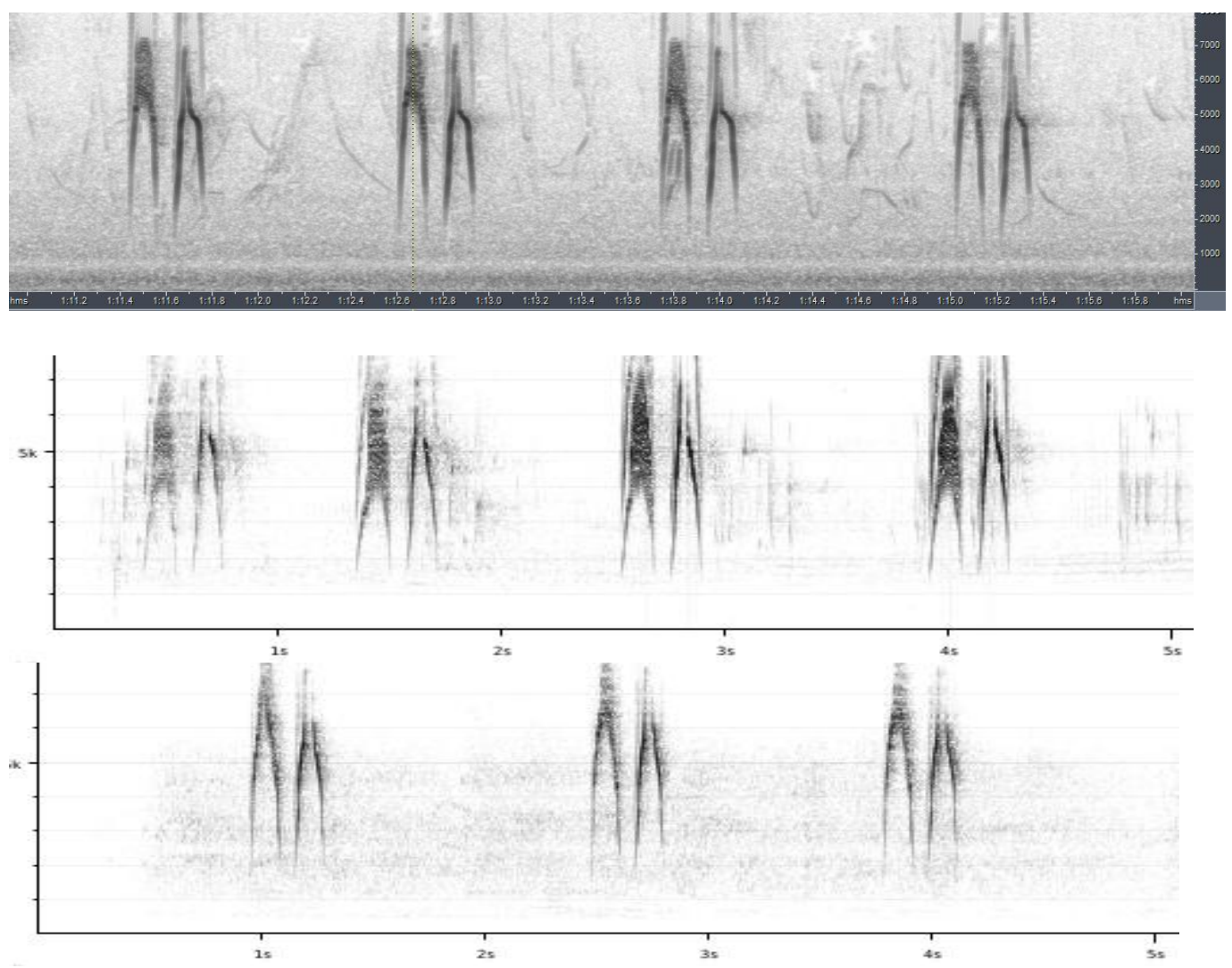

Figure 2: song from C Bolivia (top), N Argentina (middle) and C Argentina (bottom)

As this song pattern seems not to concur for $100 \%$ with the described range for S.a. australis, I have checked recordings in the southern cone to see where the change occurs.

Belongs to this southern vocal group:

* All recordings from Argentina, north to at least Taco Pozo in Chaco (no recordings of Misiones, these should be albescens).

* NW Uruguay (ML187221)

* Song E of Cochabamba, Bolivia (ML132544)

Belongs NOT to this group:

* E Paraguay (ML143382)

* N Bolivia (Beni) (ML51864)

* SE Peru (XC124854) 

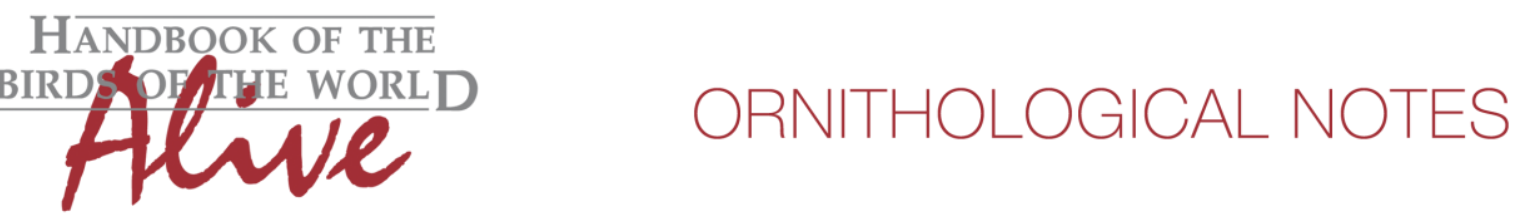

It would thus seem that (at least from vocal data) the boundaries between S.a. albescens and S.a. australis are slightly different from what is described in HBW, with birds of SE Peru and N Bolivia belonging to albescens (connected with birds from Mato Grosso, Brazil), or else australis actually involves 2 taxa (or australis has a geographically different song, which would be rather unlikely).

Without doing a further thorough analysis, it is clear that vocal difference will reach a high score, with differences as significant as e.g. compared with other Synallaxis members who have a 2-note song.

This note was finalized on 13th April 2015, using sound recordings available on-line at that moment. We would like to thank in particular the many sound recordists who placed their recordings for this species on XC and ML.

\section{References}

Tobias, J.A., Seddon, N., Spottiswoode, C.N., Pilgrim, J.D., Fishpool, L.D.C. \& Collar, N.J. (2010). Quantitative criteria for species delimitation. Ibis 152(4): 724-746.

\section{Recommended citation}

Boesman, P. (2016). Notes on the vocalizations of Pale-breasted Spinetail (Synallaxis albescens). HBW Alive Ornithological Note 105. In: Handbook of the Birds of the World Alive. Lynx Edicions, Barcelona. (retrieved from http://www.hbw.com/node/932010 on 25 July 2016). 